\title{
Three Decades of External Imbalances and Macroeconomic Fundamentals: The Case of Turkey
}

\author{
Bilge Gursoy \\ Kadir Has University, Istanbul, Turkey
}

\begin{abstract}
The paper aims to investigate the current account imbalances in the context of an overview of macroeconomic fundamentals after the liberalization process in Turkey. Two main questions discussed here are: (1) What is the link between liberalization and current account imbalances; (2) What kind of mechanisms ensured this link to become a vicious circle. The period after 1989, Turkey was characterized by significant fluctuations in macroeconomic activity by the implementation of liberalization policies. Once financial liberalization is adopted, Turkey faced with a new challenge: large current account deficits. On the other hand, foreign capital inflows aggravated a lending boom. Because of excessive risk taken by banks, interest rates began to rise. As mentioned above, the paper studies Turkey's liberalization process with a number of indicators that point to a fragility of the external balance: unhealthy structure of financial sector, particularly banking sector, large fiscal imbalances, low savings and investment rates, unstable GDP growth. Domestic structural features combining with macroeconomic policy stance and political factors are examined as well.
\end{abstract}

Keywords: current account imbalances, macroeconomic fundamentals, financial liberalization, Turkey

\section{Introduction}

For more than three decades, a series of liberalization (trade and financial) policies have been cited as a necessary and significant part of an economic policy package in developing countries. The motive behind these policies was to restore growth and stability by reducing the cost of capital, increasing both savings and investment. Turkey, as a developing country, implemented liberalization policies after 1980 and completed this process through financial liberalization in 1989.

Since the late 1980s, macroeconomic and political developments under the neo-liberal model is observed to suffer from persistent difficulties as widening current account deficits, fluctuations in national income and expanding fiscal deficits. As a result, weak financial structure and macroeconomic fundamentals of domestic economy triggered financial crises with severe economic and social consequences.

Three important and basic questions are regularly asked in assessing the severity of external imbalances (Milesi-Ferretti \& Razin, 1996): Is the debtor country solvent? Is the current account deficit excessive? Are current account imbalances sustainable? In this study, the theoretical debates on these notions shall not be

Bilge Gursoy, Ph.D., International Trade and Logistics, Kadir Has University.

Correspondence concerning this article should be addressed to Bilge Gursoy, Kadir Has University, Selimpasa Kampusu, Selimpasa, Istanbul, Turkey. E-mail: bgursoy@khas.edu.tr. 
handled. The main aim is to analyze the current account sustainability in the macroeconomic policy stance, as well as in the external environment.

There are three main traditional approaches to the balance of payments adjustments. These are elasticities, the absorption and the monetary approaches (Mwau \& Handa, 1995, p. 28). However, these approaches have remained incapable to explain the new economic developments upon the oil crises in 1970s. This resulted from the fact that many countries confronted excessive current account deficits due to the increase in oil prices. Modern macroeconomic models of the open economy have emphasized the fact that current account is an intertemporal phenomenon.

Intertemporal analysis of the current account became an active area of research in the early 1980s. These models of current account determination are based upon the permanent-income or life cycle hypothesis.

For the last 25-30 years, the empirical methods used to analyze the current account behavior are based on one or another of the above theoretical methods. The existing studies in the literature have tended to explain the persistence of current deficits in developing countries by reference to two main factors: exogenous factors beyond the countries' control and inappropriate government policies. The technique developed by Balassa has been widely applied in studying the experiences of structural adjustment in developing countries and how did they respond to external shocks during the oil crises $(1973,1979)$. Another method for analyzing the current account behavior involves the use of CGE models which generally retain intertemporal optimization framework.

The recent approach to assessing current account sustainability is to develop an empirical frame for predicting balance of payments crises using economic and financial indicators. The predictability of balance of payments crises has been examined in a number of papers (Eichengreen, Rose, \& Wyplosz, 1996; Frankel \& Rose, 1996; Kaminsky, Lizondo, \& Reinhart, 1998; Berg \& Pattillo, 1999). Although these studies differ widely in crisis episodes considered and methodologies used, some general conclusions can be drawn. First, wide variety of variables is needed to explain all balance of payments crises. This is because some indicators (reel exchange rates, international reserves) do seem to have predictive power for many crises but the others not (Abiad, 2003).

More recently, unit root and cointegration tests have been carried out to analyze both solvency and sustainability (Husted, 1992; Wickens \& Uctum, 1993; Baharumshah, Lau, \& Fountas, 2003; Holmes, 2006). These studies generally focus on the developed countries and less on developing countries.

It is the purpose of this paper to identify and study the several potential indicators of current account sustainability, particularly focusing on the economic structure, macroeconomic policy and political environment. The analysis includes the period between 1989 and 2008. In the base period, the economic growth, openness and trade, savings and investment, reel exchange rates and external liabilities closely related to the current account deficits are handled as macroeconomic indicators. Financial intermediation and political instability are also discussed.

The paper is organized as follows. Section 2 presents the relationship between current account deficits and macroeconomic fundamentals. The next section discusses the role of the financial system. Section 4 shows the relationship between current account deficits and currency crises in Turkey. Section 5 summarizes and concludes.

\section{Current Account Imbalances and Macroeconomic Fundamentals}

In this section, the author discusses several potential indicators to evaluate the sustainability of current 
account deficit in Turkey after the liberalization process. Therefore, it is examined a broad set of macroeconomic and structural indicators. Subsequently, the developments in financial system and the impact of politic developments in this period and effecting mechanisms will be argued.

From Figure 1, it can be observed the general overview of the current account deficit of Turkey. During 1980-1988, classical accumulation model had been adopted with common characteristics, in order to increase exports, creating domestic demand contraction resulted from wage suppression, and export promotion with strong subsidy components, together with the managed floating of the exchange rate and regulated capital movements. As a result of these polices, current account deficit/GDP ratio in which it is growing is slow down and the possibility of financing is definitely improving.

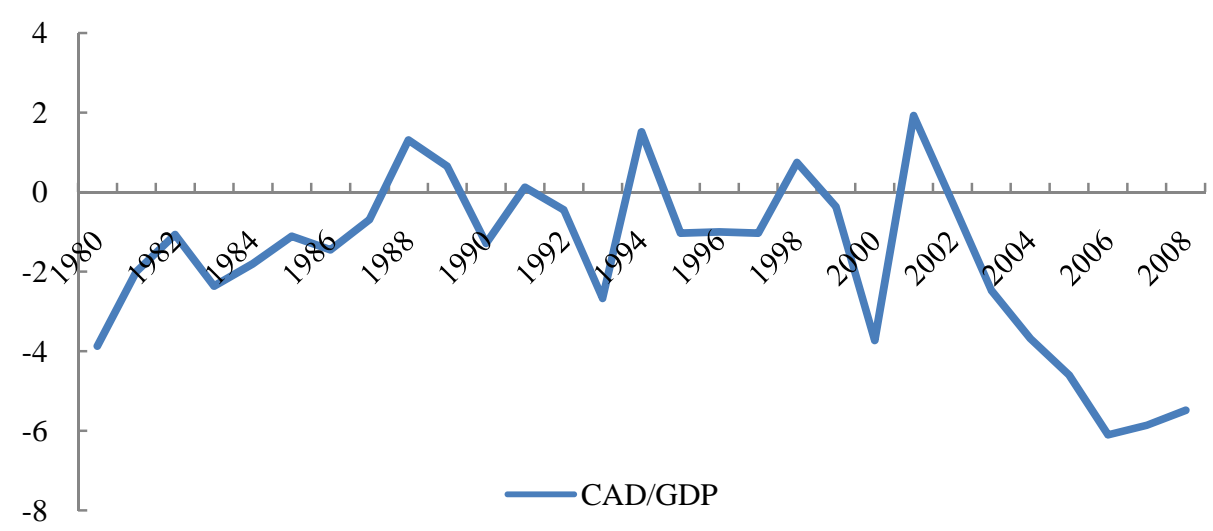

Figure 1. Turkey’s current account deficit as percentage of GDP, 1980-2008.

The turning point in economic policies of the post-1980 was the liberalization of the capital account in August 1989. The weak and fragile nature of the Turkish economy contributed to the rise of serious crises in 1994, 1998-1999, and 2000-2001. Due to 2002, current account path reflects the unstable characteristics of the domestic economy. After 2002, Turkish foreign trade has increased tremendously, and the current account deficit which is high by any standards at its average annual rate is 4.7 for the six years (2003-2008).

After 2000/2001 crisis, the Turkish economy recovered as a result of bold domestic reforms. Macro stability was attained first, and it was completed in the area of privatization, trade liberalisation, labour market and in particular by a thorough reform of the banking sector. During 2002-2007, according to robust recovery, relatively large current account deficit surfaced. In 2007, the current account deficit/GDP ratio was realized as 5.8 percent which is higher than the traditional danger point for current account deficits. This trend has continued but slow downed in 2008, and it was contracted with the global economic crisis in 2009.

\section{Structural Features, Macroeconomic Policy Stance and Political Instability}

\section{Economic Growth}

The 24th January 1980 decisions were announced to attain a more outward-oriented and market-based economic system. The main aim of such effort of liberalization policy and integration of the economy into the world financial system was to achieve higher economic growth.

Figure 2 shows that, over the past 25 years, Turkey’s economic growth performance has been weak and volatile. Turkey's post-1980 macroeconomic history could be divided into three distinct (1980-1988, 1989-1998, 
and 2002 till now) phases, and there is some similarities between the 1980s and 2000s. The similarity is on the trend of the GDP growth which is upgrading and less volatile when it is compared with the 1990s. In the first phase, between 1980-1988, GDP grew at a rate of 4 percent per annum, while in the period 1989-1998, the average annual growth rate was around 4.4 percent, and in the period 2002-2008 it was 6 percent.

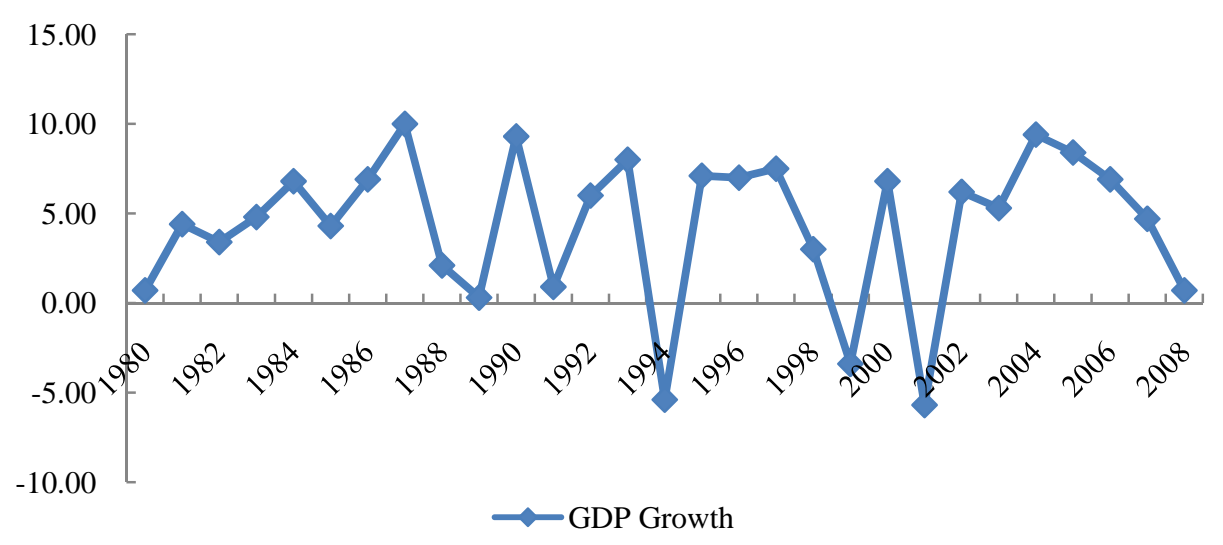

Figure 2. GDP growth (annual percentage change), 1980-2008.

A wide range of studies has investigated the factors underlying economic growth. However, there is a general consensus that the main driving forces for economic growth are: investment and total factor productivity. In Turkey, the composition of total fixed investments after 1980s reflects the characteristics of the economic policies. Fixed investments of the public sector intensified infrastructure investments like energy and transportation. On the other hand, only a small proportion of fixed investments of the private sector was directed to manufacturing.

In 1987, the fixed investments of private sector in agriculture, mining and manufacturing, which are considered as the main productive sectors, realized as 32.5 percent. On the other side, in the same year, only housing investments was 45.7 percent. These ratios show that both the official stance and private sector is so far from industrialization.

Another crucial factor for economic growth is the ability to continue to enhance the quality of capital and human resources. This will be achieved by technological advancement and knowledge-based growth. Investment in human capital, such as basic skills, quality training and funding continuing education, is a key factor for economic and social performance. According to OECD 2008 report, the public education expenditures as a percentage of GDP was 3.8 percent for all education levels in Turkey, while the average of OECD member countries was actualized as 5 percent. Based on the given data, Turkey has not have the lowest average in respect of this indicator, however, it falls behind the general average. Again according to the OECD 2008 report, the annual education expenditures per student was $\$ 1,428$, while the average of OECD member countries was $\$ 6,962$, which is an extremely higher figure.

R\&D activities and innovation can play a major role in increasing economic growth and productivity. This is due to increasing use of technology that enables introduction of new products and processes. The main indicators used for international comparisons are gross domestic expenditure on $R \& D$ (as a percentage of GDP), the number of researchers (per thousand employed) and exports of ICT equipment. Turkey has improved the 
coverage of their surveys of R\&D activities and in higher education after 1990s, however, it has been described as a lower technology country in respect of these three indicators.

Finally, we need to analyze the sectoral composition of growth. A look at the Turkey GDP composition sector wise throws up some interesting figures after 1980s. The agriculture sector contributed 24.4 percent, industry contributed 20.7 percent, while the service sector had a contribution of 54.8 percent in 1980 . The share of main productive sectors in GDP has changed dramatically, 9, 23.8 and 67.2 percents respectively, in 2008. The data shows us that there is a significant change in sectoral composition of growth, however, it does not mean that Turkey is an industrialized country.

\section{Openness and Trade}

Broadly speaking, there are two competing views on the relationship between a country's openness, and it is likely to face external sustainability problems. The first view is that openness makes the country more vulnerable to terms of trade shocks and to restrictive trade policies in other countries. The second view is that countries that are open to international trade are less vulnerable to external shocks coming from abroad. This is because, a large export sector strengthens the country's ability to service its debt obligation.

A number of measures of openness have been used in different empirical studies. Table 1 reports most popular and traditional measures: exports/GDP, (exports + imports)/GDP and (exports + imports)/2 as percents of GDP in Turkey. As Table 1 shows, the ratio of exports and imports to GDP, the most popular measure of openness, shows an upward trend between 1980 and 2008, and the rate rising from 11 percent in 1980 to 45 percent at the end of 2008. When we compare this ratio with another traditional measure, exports/GDP, it could be observed that there is a significant difference between the ratios, whether the latter has a much less drastic movement. The exports/GDP ratio also increased but the rate of increase was smaller as it went up from 3.1 percent to 19 percent during the same period. The reason for this is that Turkish economy's ability to export is excessively dependent on imports.

The export-led growth policy is quite successful in the early stages of its implementation. As emphasized above, total exports/GDP ratio increased three fold during the period 1980-1988. The total imports/GDP ratio increased from 8.4 percent to 11.2 percent during the same period. Therefore, the external balance improved significantly.

The developments after 1987, has an adverse effect on the external balance. Because of the appreciation of the Turkish Lira, the rate of increase in the exports slowed down and the imports jumped up. The foreign trade deficit increased to $\$ 4.1$ billion in 1989 and to $\$ 8$ billion in 1992. Towards the end of 1993, it was clear external balance unsustainable, it reached to 5.9 percent of the GDP.

In January 1994, Turkey's credit rating was downgraded by some major international agencies. This caused a panic in financial markets and the Turkish Lira devaluated, the parity more than doubled from about 15,000 $\mathrm{TL} / \$$ to $35,000 \mathrm{TL} / \$$ within the few months. Thus the capacity of Turkey to service its growing external debt was severely impaired and Turkish economy hit by the 1994 currency crisis.

The customs union formed between Turkey and European Union in 1996 further liberalized Turkish foreign trade by removing all trade barriers between the two parties. When we go back to Table 1, it shows us, the openness degree ((export + import)/GDP) increased to around 30 percent after 1996. The contagion effects of the Asian and the Russian crises brought about a protracted crisis in Turkey in 1998 and 1999. For the rest of the decade, the trade balance was the main determinant of the current account balance. 
Table 1

Macroeconomic Indicators

\begin{tabular}{|c|c|c|c|c|c|c|c|c|c|}
\hline Year & $\begin{array}{l}\text { Exports/ } \\
\text { GDP (\%) }\end{array}$ & $\begin{array}{l}\text { Exports+ } \\
\text { imports/ } \\
\text { GDP (\%) } \\
\end{array}$ & $\begin{array}{l}\text { (Exports+ } \\
\text { imports/2/ } \\
\text { GDP }(\%)\end{array}$ & $\begin{array}{l}\text { National } \\
\text { savings/ } \\
\text { GDP (\%) } \\
\end{array}$ & $\begin{array}{l}\text { Total fixed } \\
\text { investment/ } \\
\text { GDP (\%) }\end{array}$ & $\begin{array}{l}\text { Real exchange } \\
\text { rate }(1987=100)\end{array}$ & $\begin{array}{l}\text { Portfolio investment } \\
\text { (U.S. \$ million) }\end{array}$ & $\begin{array}{l}\text { FDI stocks } \\
\text { (U.S. \$ million) }\end{array}$ & $\begin{array}{l}\text { FDI stocks } \\
\text { (U.S. \$ million) }\end{array}$ \\
\hline 1980 & 0.03 & 0.11 & 0.06 & 16 & 21.8 & - & & 8.840 & 18 \\
\hline 1981 & 0.05 & 0.14 & 0.07 & 18.3 & 19.8 & - & & 8.935 & 95 \\
\hline 1982 & 0.07 & 0.17 & 0.08 & 17.1 & 19.2 & - & & 8.990 & 55 \\
\hline 1983 & 0.07 & 0.18 & 0.09 & 16.5 & 20.1 & - & & 9.036 & 46 \\
\hline 1984 & 0.09 & 0.21 & 0.11 & 16.5 & 19.3 & - & & 9.149 & 113 \\
\hline 1985 & 0.09 & 0.21 & 0.10 & 18.9 & 20.1 & - & & 9.248 & 99 \\
\hline 1986 & 0.07 & 0.18 & 0.09 & 21.9 & 22.8 & - & 146 & 9.373 & 125 \\
\hline 1987 & 0.09 & 0.20 & 0.10 & 23.9 & 24.6 & 98.8 & 307 & 9.488 & 115 \\
\hline 1988 & 0.10 & 0.21 & 0.10 & 27.2 & 26.1 & 98.0 & 1.184 & 9.842 & 354 \\
\hline 1989 & 0.08 & 0.19 & 0.10 & 22.1 & 22.5 & 106.4 & 1.445 & 10.505 & 663 \\
\hline 1990 & 0.06 & 0.18 & 0.09 & 22 & 22.6 & 123.1 & 681 & 11.189 & 684 \\
\hline 1991 & 0.07 & 0.17 & 0.09 & 21.4 & 23.7 & 128.2 & 714 & 11.999 & 810 \\
\hline 1992 & 0.07 & 0.18 & 0.09 & 21.6 & 23.4 & 126.1 & 3.165 & 12.843 & 844 \\
\hline 1993 & 0.06 & 0.19 & 0.09 & 22.7 & 26.3 & 133.8 & 4.480 & 13.479 & 636 \\
\hline 1994 & 0.11 & 0.23 & 0.12 & 23.1 & 24.5 & 101.3 & 1.123 & 14.087 & 608 \\
\hline 1995 & 0.10 & 0.25 & 0.13 & 22.1 & 24 & 110.0 & 703 & 14.972 & 885 \\
\hline 1996 & 0.13 & 0.31 & 0.16 & 19.9 & 25.1 & 114.0 & 1.950 & 15.694 & 722 \\
\hline 1997 & 0.13 & 0.32 & 0.16 & 21.3 & 26.3 & 121.6 & 2.344 & 16.499 & 805 \\
\hline 1998 & 0.12 & 0.28 & 0.14 & 24.3 & 23.1 & 132.9 & -5.089 & 17.439 & 940 \\
\hline 1999 & 0.12 & 0.28 & 0.14 & 20.1 & 19.3 & 140.3 & 4.188 & 18.222 & 783 \\
\hline 2000 & 012 & 0.32 & 0.16 & 18.4 & 20.8 & 152.0 & 1.615 & 19.204 & 982 \\
\hline 2001 & 0.18 & 0.38 & 0.19 & 18.4 & 16.4 & 123.1 & -3.727 & 19.677 & 3.352 \\
\hline 2002 & 0.18 & 0.38 & 0.19 & 18.6 & 17.1 & 137.7 & 1.503 & 18.795 & 1.082 \\
\hline 2003 & 0.17 & 0.39 & 0.19 & 15.5 & 17.4 & 151.7 & 3.851 & 33.537 & 1.702 \\
\hline 2004 & 0.17 & 0.41 & 0.20 & 16 & 20.7 & 162.1 & 9.411 & 38.523 & 2.785 \\
\hline 2005 & 0.16 & 0.39 & 0.20 & 15.9 & 21.4 & 179.6 & 14.670 & 71.299 & 10.031 \\
\hline 2006 & 0.18 & 0.43 & 0.22 & 16.5 & 22.6 & 179.8 & 11.402 & 95.078 & 20.185 \\
\hline 2007 & 0.17 & 0.42 & 0.21 & 16.1 & 21.9 & 198.96 & 2.780 & 157.649 & 22.046 \\
\hline 2008 & 0.19 & 0.45 & 0.23 & 15.9 & 21.6 & 202.3 & -3.770 & 69.871 & 18.198 \\
\hline
\end{tabular}

Between 1980 and 2008, total export has increased from \$ 2.9 billion to \$ 140.7 billion. The structure of exported goods has also changed much from mainly agricultural products and raw materials to higher value added industrial products. Transformation still continues with increasing exports of transportation vehicles and office equipments. When exports by main sectors are examined, there seems to be a steady decrease in the share of exports of agricultural products until 2008. The share of export of agricultural products in total exports decreased from 47.2 percent in 1990 to 3.1 percent in 2008. On the contrary, export of industrial products increased its share in total exports from 48.7 percent in 1981 to 94.8 percent in 2008.

Total imports have increased from $\$ 7.9$ billion to $\$ 193.9$ billion between 1980 and 2008. In contrast to the structure of exported goods, the composition of imported goods did not change significantly in the same period. Specifically, intermediate goods have the biggest share which is changing in between 66-79 percent during 1980-2008. As a result, one can suggest that Turkish exports excessively dependent on imports. 


\section{Savings and Investment}

Another potential indicator of external sustainability is the level of national savings and investment. Higher saving rate is expected to affect economic growth positively by increasing the available amount of financial capital for investment which may be used for increasing the rate of capital accumulation. High levels of investment imply higher future growth through the buildup of a larger productive capacity.

Nonpolicy determinants of savings include persistence, income, growth, demographics, and uncertainty. In developing countries, generally the low levels of per capita income and uncertainty regarding the macroeconomic and political environment are the most influential ones. In addition to these factors, economic policies, fiscal policy, financial liberalization and external borrowing, may also affect savings directly and indirectly.

The figures in Table 1 show the domestic savings and investment rates (as a percentage of GDP) of Turkey. In Turkey, after the implementation of a structural change and reform program in 1980, governments have tried to raise private saving rates through interest liberalization, direct tax incentives and capital market reforms. As seen from the Table 1, the national saving rates (as percentage of GDP) increased from 16 percent in 1980 to 22 percent in 1990, and the average annual rate for the same period was around 20 percent. During 1990-1999, the national saving rate continued to increase and averaged annually 21.8 percent. After 2000, it began to decrease sharply and the average annual national saving rate was 16.8 percent between 2000 and 2008.

As mentioned before, in Turkey, economic policies, especially fiscal policy had adverse effects on the private saving and investment in the post-1980 process. After 1986, the public sector borrowing requirement (PSBR) as a percentage of GDP started to increase in a steady fashion and reached 7.9 percent in 1992. Financing the budget deficits through domestic borrowing has led to increase in domestic interest rates. The private sector began to finance the public deficits through public securities particularly after 1990. During the 1990s, higher government expenditure which is generally financed with debt has raised the interest rates, made capital more expensive and reduced the private investment (crowding out effect).

Evidence on investment rates in Turkey is also shown in Table 1. While the average investment rate (as a percentage of GDP) between 1980 and 1990 was 21.7 percent, it is observed that the rate increased to 23.6 percent in years between 1990 and 2000, however, it decreased to 19.9 percent after 2000, during 2001-2008 period (particularly because of the economic crisis in 2000/2001). According to these developments, it can be stated that Turkey has showed a worse performance in comparison to the other developing countries.

Table 2

Incremental Capital Output Ratio (ICOR) (\%)

\begin{tabular}{lclcc}
\hline Sector & $1985-1989$ & $1990-1994$ & $1996-2000$ & $2001-2005$ \\
\hline Manufacturing & 3.3 & 6.2 & 6.5 & 5.2 \\
Energy & 12.3 & 7.2 & 13.9 & 10.2 \\
Transportation & 11.6 & 8.1 & 10.5 & 6.3 \\
Total & 5.1 & 7.5 & 6.9 & 4.6 \\
\hline
\end{tabular}

There are several reasons why high investment rates should have been regarded with concern with regards to current account sustainability. The profitability of the investment projects is provided by a standard measure of investment efficiency, the incremental capital output ratio, computed as the ratio of fixed capital in real terms to the change in real GDP. Although it does not provide information about the rates of return across sectors and 
sectoral allocation of bad investments, it provides a broad estimate of the capital productivity. Table 2 presents four sets of data, 1985-1989, 1990-1994, 1996-2000 and 2001-2005 period by manufacturing, energy and transportation sectors. The data for the periods suggest that investment efficiency is generally volatile and low in Turkey. Finally, the overall picture is quite clear: In Turkey, the most productive sector is manufacturing during 1985-1989 and 2001-2005.

\section{Exchange Rate}

In the context of structural adjustment programme in progress since 1983, one of the main element of this package to promote exports was gradual and significant depreciation of the Turkish Lira. The strategy of early 1980s was quite successful. On the other hand, the export-growth path which was dependent on depreciation of domestic currency, reached its economic limits by 1987. In this context, if it is called as the period 1984-1987 as deepening of liberalization, after 1988, Turkish economy entered a new phase and policy makers started to slow down the depreciation rate of the Turkish Lira.

Table 1 presents the data of the real exchange rate of Turkey. The data shows that after 1994 currency crisis, the Turkish Lira continued to appreciate. High domestic interest rates have stimulated foreign inflows and led to appreciation of the domestic currency further invited an even higher level of "hot money" inflows into the domestic financial markets. All these developments caused a "high interest rate-low exchange rate policy" which has worked against the competitive dynamics, particularly in the production sectors.

In 2000, Turkey implemented a new dis-inflation program designed and supervised by the IMF. In terms of CPI and WPI, the program targeted 25\% and 20\% inflation rates for the two indices at the end of 2000. At the same time, it programmed a 20\% increase in the nominal TL price of a basket of 1 US \$ + 0.77 Euro (Boratav \& Yeldan, 2001). But it was short-lived, following two crises in November 2000 and February 2001, the crawling peg system was ended to be placed by a floating exchange rate system.

After the implementation of successive structural reforms in the post-2002 era, the quality of fiscal performance across the major sectors of the economy improved significantly. Turkey also achieved remarkable success towards achieving price stability. Thus, inflation declined in a period when the Turkish Lira appreciated considerably in real terms starting from 2002. As Table 1 shows, between 2002 and 2008, TL continued to appreciate. During the same period, sharp appreciation of the Turkish Lira resulted from large capital inflows to Turkey. But then, sudden stops and reversals of capital inflows which intensified with the global crisis of 2008-2009, brought uncertainty to the economy.

\section{External Liabilities}

The composition of the capital inflows is a significant determinant in current account sustainability (Roubini \& Wachtel, 1998, p. 7). Short-term capital inflows are dangerous than long-term flows and equity inflows are more stable than debt-creating inflows. External sustainability also depends on the currency composition of a country's foreign liabilities.

The 1980 stabilization and liberalization programme has introduced a major policy shift from the import substitution strategy towards a more outward-oriented strategy which has attracted the foreign investors in Turkey. Table 1 presents this trend in the level of annual inflows and stocks. For the period 1980-1999, the amount of foreign capital stocks reached a total of \$ 17.4 million. 
Turkey has always attracted very low inflows of FDI relative to the other comparable countries. Structural barriers, heavy bureaucratic requirements, macroeconomic instability, corruption and political uncertainty are some of the primary causes of low levels of FDI in Turkey. As mentioned before, it only attracted \$ 17.4 million foreign capital in 19 years. According to UNCTAD World Investment Report 2002, the minimum annual FDI attraction potential of Turkey is \$ 35 million. However, it could only attract FDI of annually \$ 1 million since 1990 on the average.

Turkey recorded a substantial increase in the level of FDI stocks from 1999 to 2007. During the same period, the FDI stocks increased from \$ 182 billion in 1999 to \$ 157.6 billion in 2007. This increase could be attributed in part to series of investment-related reforms, additionally a programme of privatization which Turkey has implemented in 2003, in order to improve the investment climate and to attract the FDI. After 2003, a close relationship has developed between privatization and FDI in Turkey. Also, privatization has become a major conduit for FDI. During 2000-2006, the share of FDI inflows in total privatization was 25.9 percent and could be defined as the dominant form of privatization. However, it has to be mentioned that this case will not carry on at the same rate and speed while considering the limited resources.

The FDI inflows to Turkey, between 1980 and 2003 have been predominantly in the manufacturing sector, with the share of manufacturing sector in FDI being around 53 percent of total FDI inflows. In the recent years, the sectoral composition of FDI flows has been transformed in Turkey as in the worldwide, with a shift towards the services sector. After 2002, in response to Turkey's efforts to privatize and liberalize the infrastructure and financial sectors, most of the FDI in services have been directed to these sectors. It is observed that during 2002-2007, FDI in service sector generally concentrated on the transportation, communication and financial sector.

As regards the FDI, while production technology and know-how are also brought in along with the capital, and in the portfolio investment which includes equity and debt securities, the sole contribution is capital. On the other hand, portfolio investment can be much more volatile compared with direct investment. During external crises, many of the emerging market economies have experienced a surge in capital flows and suffered an abrupt capital account reversal or sudden stop which can be defined as large and unexpectedly fall in capital inflows occurring in conjunction with a sharp rise in credit spreads (Calvo \& Reinhart, 1999).

As seen from the Table 1, after 1986 the main characteristic of the portfolio investment in Turkey is volatility. Another factor emerging from the table is, nearly all the banking and currency crises (1994, 2000, 2001) in Turkey are associated with a negative reversal in capital inflows, particularly in portfolio investment. From 1993 to 1994, portfolio investment decreased from $\$ 4.4$ billion to $\$ 1.1$ billion, adjusting to about 74 percent. Portfolio investment declined from \$ 2.3 billion in 1996-1997 to \$ -5 billion in 1997-1998. This decline in portfolio investment is mainly attributable to the contagion from the East Asian crisis, which adversely affected capital flows to all emerging markets. International and domestic developments continued to affect capital flows into Turkey in 2000-2001 as well. The portfolio investment was realized \$ 1.6 billion and \$ -3.7 in 2000 and 2001, respectively, that was very low level when it compared to the inflow of $\$ 4.1$ billion during the corresponding period in 1999. In corollary, sudden stops led to collapses and do severe damage to the financial system in Turkey.

\section{Political Instability and Policy Uncertainty}

In addition to unsatisfactory macroeconomic indicators, political instability and uncertainty may accelerate 
balance of payments crisis in any country (Bussiere \& Mulder, 2000). Therefore, one may argue that political instability worsens the balance of payments. At this point, the author would like to summarize political situation in Turkey since 1980s. After 1983 general election, Turkey got rid of military regime. Motherland Party which is in favor of neo-liberalism, governed Turkey from 1983 to 1991 by winning the general election twice. In this period, Turkey adopted and implemented neo-liberal economic policies, particularly in financial area thanks to stable government.

Contrary to 1980s, there were high risk perceptions in financial markets because coalition party governing took single party's place in 1990s. It is because coalition governments were always perceived as the source of political instabilities and uncertainties in Turkey. For example, in 2001, the cause was a cracking coalition and the Constitution being thrown at a prime minister's face. By literally throwing the Constitution at the late Prime Minister Bülent Ecevit, president Ahmet Necdet Sezer unexpectedly caused an economic crisis, leading the economy to contract 5.7 percent (Van Rijckeghem \& Ucer, 2005, p. 77). Besides, Turkey faced several serious national and international problems as well, for example, First Gulf War (1991) as an international issue caused regional problems for Turkey. PKK terrorist organization at national level was violating the political order within Turkey, in brief, political instability and uncertainty dominated 1990’s Turkey.

From 2002 to 2008, Turkey regain political stability because JDP (Justice and Development Party) alone was able to form a government. During this period, the government was managed to keep economic stability and grade macro-economic indicators. However, because of 2008 global economic crisis, JDP failed to continue economic stability as it managed between 2002-2007 period.

\section{The Role of the Financial System}

In the previous section, a number of country specific factor that determined the current account imbalances have highlighted. In this section, the banking and financial sector in Turkey will be analyzed.

Particularly after the 1980s, toward the liberalization of financial markets in Turkey, the government planned to develop an efficient and competitive financial system that would support to facilitate the functioning of a liberal economy. Reforms eliminated interest restrictions on deposits and loans, and eased entry into the market and permitted new types of financial instruments and institutions. In addition reforms contributed to financial deepening, revitalization of the stock market, quality of financial services and product variety.

This liberalization process culminated in the opening of capital account in 1989 which increased the funding options abroad both for the financial system and large corporations. As a result, by 1990 Turkey had minimal constraints on domestic and external financial intermediation.

Since 1990, requirement of the public sector financing and the macroeconomic imbalances have shaped the development and the evolution of the financial system. The main source of the financial system problem was fiscal deficits, which ultimately reflected Turkey's inability to deal with the underlying causes of poor public finances in the same period. These developments gave rise to three severe financial crises in 1994, 2000 and 2001, each of which was followed by the collapse of the economy.

In Turkey, with bond and equity markets relatively underdeveloped, most financial intermediation occurred through the banking system. This meant that the capital inflows, financing the Turkey's current account deficit was largely intermediated by local banks. Especially after financial opening in 1989, domestic banks borrowed 
from foreign banks, and then in turn lent on to domestic firms. Subsequently, when the domestic firms experienced financial difficulties, domestic banks were faced with non-performing domestic assets and short-term foreign currency liabilities. In the same period, monetary and exchange policies also encouraged foreign borrowing.

In the literature, the most commonly used measures of financial development are the ratio of broad money (generally M2) to GDP, the ratio of private sector to GDP and the ratio of domestic credit to GDP. M2/GDP ratio measures the monetization in the economy. Figure 3 presents the Turkey's monetary aggregates as a percentage of GDP (M1, M2, M2Y) between 1986 and 2008 period. As seen from the figure, M1/GDP ratio was stable in this period, in sharp contrast to M2/GDP and M2Y/GDP ratios. Thus, one can suggest that the broad money rose faster than the narrow money, because financial deepening has occurred. On the other hand, specifically after 1990s, the difference between M2/GDP and M2Y/GDP has increased due to dollarization which was occurred as a result of high and volatile inflation.

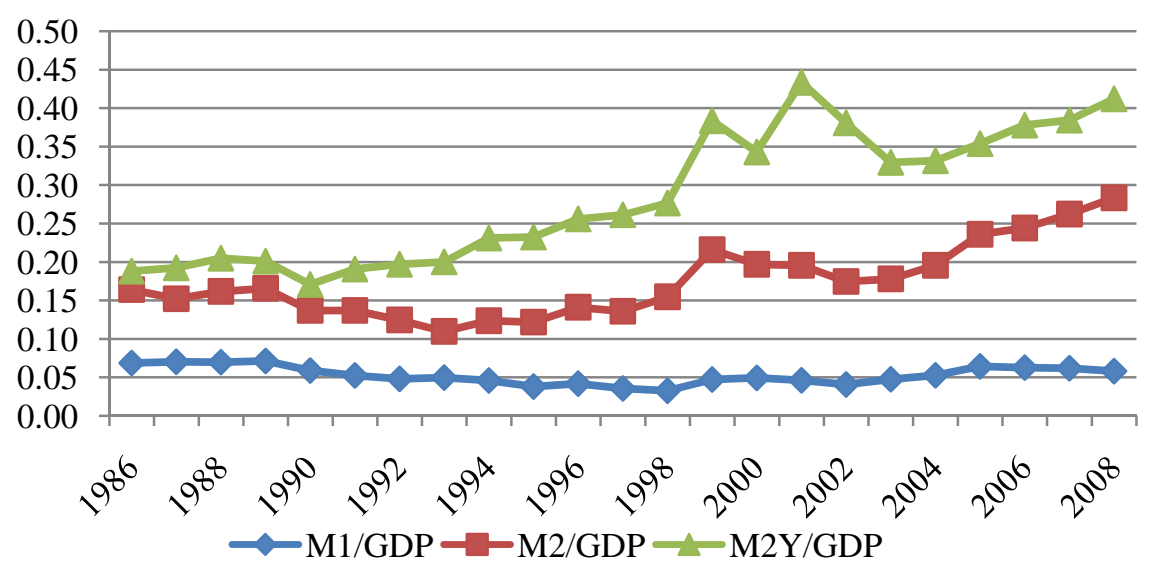

Figure 3. Financial development indicators: Monetary aggregates (1986-2008).

Another proxy for financial development is the share of private sector credit in GDP. From 1986 to 2008, the ratio had an upward trend, particularly after 2005, but it was quite volatile in the same period. In addition, the ratio of domestic credit to GDP can be defined as an indicator of financial development, which represents the domestic assets of the financial sector. This series also had an upward trend and volatility, as the private sector credit ratio, during 1986 and 2008 period.

As mentioned before, Turkish banking sector remains the locomotive of the financial system. After 2001 banking and currency crises, the banking reform was skillfully handled under challenging circumstances. The strengthened independence of The Central Bank of Turkey and the establishment and the efficient functioning of the Banking Regulation and Supervision Agency (BRSA) were crucial in this respect. In recent developments, 2008 global crisis showed that Turkey’s financial sector operates on a sounder basis and definitely less vulnerable to external and domestic shocks.

\section{Currency Crises and Current Account Sustainability}

Recent currency and balance of payments crises have stimulated new theoretical and empirical research to provide a conceptual framework that helps understand and model policy options to minimize the likelihood of 
their occurrence. At this stage, because of the severity and frequency of currency and balance of payments crises both in developed and developing countries, early warning systems have designed to predict these crises. Early warning systems can be defined as a statistical method to predict the likelihood that a country will face a currency or balance of payments crisis (Berg, Borensztein, \& Pattillo, 2004).

The empirical literature for anticipation of currency crises with the early warning models can be classified into two broad categories. The first and the more popular approach is to use probit or logit models. The influential paper of Frankel and Rose (1996) analyzed the determinants of currency crashes and found out that the current account deficit was not significant, and in many of the regressions, it had the wrong sign. Edwards (2001) studied the question of whether larger deficits increase the probability of a country experiencing a currency crises and suggested that this question depends on the definition of crisis and the sample used in the analysis. Callen and Cashin (2002) used multivariate probit model for a panel of 23 developing economies, including India. The main focus of the paper is external sustainability and currency crises. Kruger, Osakwe and Page (2000) examined the determinants of currency crises using a panel of annual data for 19 developing countries with a probit model linking macroeconomic variables. Specifically, they find that an increase in the current account deficit, increases the probability of a currency crisis.

The second approach to predict currency crises is signals approach. Probably, the most prominent model of this approach is Kaminsky, Lizondo and Reinhart's (1998) which does not include current account as a signaling indicator. In contrast, Berg and Pattilo (1999) re-estimated the KLR model and added the current account/GDP and M2/reserves ratio indicators. They compared the original KLR model predictions with a probit-based alternative and argued that current account deficit is a significant indicator for anticipating currency crises.

In the literature, there is few studies focused on analyzing both Turkish currency crises and the relationship between current account sustainability and currency crises episodes. Mariano, Gultekin, Ozmucur, Shabbir and Alper (2004) examined the Turkish post-capital account liberalization experience in the perspective of 1994 and 2001 crises. They implemented Markow switching autoregressive model and predicted the crises of 1994 and 2001. They showed the real exchange rate, foreign exchange reserves and domestic credit/deposit ratio are the most significant indicators of financial vulnerability.

\section{Conclusion}

The aim of this paper was to investigate the relationship between current account balance and macroeconomic fundamentals of the Turkish economy during the post-1980 liberalization era. With the perspective of current account sustainability, there are key points to be highlighted. The current account deficits could become more sustainable in terms of structural features, such as high investment and savings rates, stable and high economic growth, improved financial supervision quality and political stability.

First, it is mentioned that aftermath of financial liberalization policies, the rate of economic growth increased by the effect of capacity utilization improvement. Second, according to high real interest rates and currency over-valuation the portfolio investment increased and caused volatility in the financial system. The analysis also provides evidence that the main source of macroeconomic problems and financial crises is high public deficits.

In the vicious cycle of high foreign capital flows, unstable economic growth rates, large and persistent 
current account deficits, Turkish economy hit by three severe crises in the last two decades. These experiences showed that international financial integration is associated with risks in developing countries like Turkey. Moreover, the resulting political uncertainty led to an environment of policy uncertainty. To minimize these risks, Turkey would need to implement sound macroeconomic and structural frameworks, especially about external imbalances. At the same time, there is a serious systemic need to strengthen and deepen democracy and politic stability in Turkey.

While this paper has focused on the last 30 years of Turkish economy and the current account deficits after financial liberalization, it would be useful to investigate the relationship between current account sustainability and currency crises in Turkey. Lastly, there is so few empirical studies that analyze the Turkish currency crises experiences, therefore, this paper has potential avenues to consider the economic and institutional factors that contribute towards the lack of external sustainability for the future research.

\section{References}

Abiad, A. G. (2003). Early warning systems: A survey and a regime switching approach. IMF Working paper serial No. 03/32.

Baharumshah, A. Z., Lau, E., \& Fountas, S. (2003). On the sustainability of current account deficits: evidence from four asean countries. Journal of Asian Economics, 14, 465-487.

Berg, A., \& Pattillo, C. (1999). Predicting currency crises: The indicators approach and an alternative. Journal of International Money and Finance, 18, 561-586.

Berg, A., Borensztein, E., \& Pattillo, C. (2004). Assessing early warning systems: How have they worked in practice? IMF Working paper, WP/04/52.

Boratav, K., \& Yeldan, E. (2001). Turkey, 1980-2000: Financial liberalization, macroeconomic (in)-stability, and patterns of distribution. Retrieved from www.bilkent.edu.tr/ yeldane/b\&ycepa2002.pdf

Bussiere, M., \& Mulder, C. (2000). Political instability and economic vulnerability. International Journal of Finance and Economics, 5, 309-330.

Callen, T., \& Cashin, P. (2002). Capital controls, capital flows and external crises: Evidence from India. Journal of International Trade and Economic Development, 11(1), 77-98.

Calvo, G. A., \& Reinhart, C. M. (2000). When capital flows come to a sudden stop: Consequences and policy options. In P. Kenen, \& A. Swoboda (Eds.), Key issues in reform of the international monetary and financial system. Washington D.C.: International Monetary Fund, 175-201.

Corsetti, G., Pesenti, P., \& Roubini, N. (1999). What caused the Asian currency and financial crisis? Japan and World Economy, 11, 305-373.

Edwards, S. (2001). Does the current account matter? NBER Working paper serial No. 8275.

Eichengreen, B., Rose, A. K., \& Wyplosz, C. (1996). Contagious currency crises: First tests. Scandinavian Journal of Economics, 98(4), 463-484.

Frankel, J. A., \& Rose, A. (1996). Currency crashes in emerging markets, an empirical treatment. Journal of International Economics, 41, 351-366.

Holmes, M. J. (2006). How sustainable are OECD current account balances in the long run? The Manchester School, 74(5), 626-643.

Husted, S. (1992). The emerging US current account deficit in the 1980s: A cointegration analysis. The Review of Economics and Statistics, 74(1), 159-166.

Kaminsky, G., Lizondo, S., \& Reinhart, C. M. (1998). Leading indicators of currency crises. IMF Staff Papers, 45(1).

Kruger, M., Osakwe, P. N., \& Page, J. (2000). Fundamentals, contagion and currency crises: An empirical analysis. Development Policy Review, 18, 257-274.

Mariano, R. S., Gultekin, B. N., Ozmucur, S., Shabbir, T., \& Alper, C. E. (2004). Prediction of currency crises: Case of Turkey. Review of Middle East Economics and Finance, 2(2), 87-107.

Milesi-Ferretti, G. M., \& Razin, A. (1996). Current account sustainability. Princeton Studies in International Finance, No. 81.

Mwau, G., \& Handa, J. (1995). Rational economic decisions and the current account in Kenya. Ashgate Publishing Limited, Avebury.

Roubini, N., \& Wachtel, P. (1998). Current account sustainability in transition economies. NBER Working paper serial No. 6468.

Van Rijckenhem, C., \& Ucer, M. (2005). Chronicle of the Turkish financial crises of 2000-2001. Bogazici University Press.

Wickens, M. R., \& Uctum, M. (1993). The sustainability of current account deficits: A test of the US intertemporal budget constraint. Journal of Economic Dynamics and Control, 17, 423-441.

Wirjanto, T. S. (1999). Emprical indicators of currency crises in East Asia. Pacific Economic Review, 4(2), 165-183. 